\title{
KSIĘGOZBIORY ROZPROSZONE, PRZEMIESZCZONE I PRZEJĘTE. PROBLEMY ZABEZPIECZENIA, DOKUMENTACJI I INFORMACJI
}

Jedną z podstawowych cech książki jest jej mobilność - latwość premieszczania. Znacznie potęguje ona walor książki jako środka komunikacji, ale też naraża ją na liczne, dodatkowe zagrożenia. W przeciwieństwie do dzieł sztuki monumentalnej, małe tomiki a nawet pokaźne woluminy stosunkowo łatwo dają się wnosić i wynosić, ukrywać lub eksponować w dowolnie wybranym miejscu, łączyć, dzielić, tasować niczym karty. Dzieje kultury wskazują, że ruchliwa książka częstokroć najszybciej i najsprawniej pokonywała czas i przestrzeń docierając do zakątków niedostępnych dla innych, bardziej stabilnych nośników treści, ale też nie zawsze wracała do swych pierwotnych miejsc. Dotyczy to zarówno poszczególnych egzemplarzy, jak i całych zbiorów.

Wędrówki książek są więc zjawiskiem naturalnym i nieuniknionym, wynikają z samej ich istoty i funkcji. Wynikają też, niestety nader często, z niezrozumienia wartości zabytków piśmienniczych - gdy bywają lekkomyślnie rozpraszane, przeznaczane na makulaturę, porzucane i zaniedbane, albo preciwnie z nadmiernego zainteresowania - gdy padają ofiarą bibliofilskiej manii, grabieży, represji a nawet celowego wandalizmu.

Książki w świadomości powszechnej i w rozumieniu prawnym są uniwersalną wartością, dobrem kultury ${ }^{1}$. Jakkolwiek pojęcie dobra kultury bywa nieco odmiennie definiowane w różnych źródlach ${ }^{2}$, jednak jego podstawowy sens wydaje się oczywisty. Nie budzi również wątpliwości konieczność ochrony.

Według obowiązującej Ustawy o ochronie dóbr kultury i o muzeach „Celem ochrony dóbr kultury jest zachowanie, należyte utrzymanie oraz społecznie celowe wykorzystanie i udostępnienie dla celów naukowych, dydaktycznych i wychowawczych, tak aby służyły nauce oraz popularyzacji wiedzy i sztuki, stanowiły trwały element rozwoju kultury i były czynnym składnikiem życia współczesnego społeczeństwa”. Zaś sama „ochrona dóbr kultury polega na zabezpieczeniu ich przed zniszczeniem, dewastacją, zaginięciem lub wywozem za granicę, na zapewnieniu im warunków trwałego zachowania, na opracowaniu dokumentacji naukowej, ewidencji i rejestracji oraz na ich konserwacji, restauracji lub odbudowie opartych na zasadach naukowych"4.

Wszystkie te zobowiązania odnoszą się również do obiektów kultury piśmienniczej, wymienionych w Ustawie wśród „zabytków” (R. II, art. 5). Wyszczególnione tam zostały m.in.: 
„.... 8. materiały archiwalne - niezależnie od techniki ich wykonania (rękopisy, maszynopisy, druki), jak akta, dokumenty, księgi, korespondencje, dokumentacja artystyczna, techniczna i finansowa oraz fotografie, filmy, nagrania dźwiękowe i inne dokumentacje utrwalone sposobem mechanicznym.

9. materiały biblioteczne, jak rękopisy, autografy, iluminacje, starodruki, pierwodruki, druki - unikaty i inne cymelia, mapy, plany, nuty, ryciny, inne zapisy obrazu lub dźwięku, instrumentaria, opracy.

10. Kolekcje i zbiory posiadające wartość artystyczną lub historyczną jako całość, niezależnie od rodzaju i wartości poszczególnych skladników.

11. Pracownie i warsztaty wybitnych twórców i działaczy jak również dokumenty i przedmioty związane z ich życiem i działalnością".

Bibliolog może mieć zastrzeżenia co do sformułowań poszczególnych punktów (sprzeciw budzi zwłaszcza niekonsekwentna klasyfikacja obiektów zabytkowych), jednak istota sprawy - prawna ochrona książki, jako dobra kultury - jest niepodważalna. Dyskusje jakie toczą się obecnie wokół obu ustaw, słusznie uważanych za niewystarczające i przestarzałe w dzisiejszej rzeczywistości, zmierzają ku udoskonaleniu systemów zabezpieczenia substancji kulturalnej i usprawnieniu dostępu do informacji oraz do zbiorów, zgodnie z wymogami współczsności.

Wyrazem tych nieodwracalnych, a co więcej dynamicznie narastających tendencji jest międzynarodowy program Powszechnej Dostępności Publikacji (Universal Availability of Publications - UAP), prowadzony przez IFLA we współpracy z UNESCO i z natury rzeczy obowiazujący wszystkie kraje stowarzyszone, w tym również Polske. Program zainicjowany w $1973 \mathrm{r}$. stopniowo ogarnia coraz szersze obszary zagadnien ${ }^{5}$.

Podstawowym założeniem planu jest zapewnienie pełnej dostępności do wszelkich publikacji dla każdego użytkownika w każdym miejscu, czasie i formie ${ }^{6}$. Dotyczy to nie tylko współczesnej oferty wydawniczej, ale również zasobów dawnych $^{7}$, zarówno poszczególnych egzemplarzy jak też całych zespołów - księgozbiorów historycznych.

Pod tym pojęciem można rozumieć ogromnie zróżnicowane struktury obejmujące od kilku czy kilkunastu pozycji (np. w odniesieniu do starożytności lub średniowiecza) po wielotysięczne zbiory rękopisów, druków, map, rycin, muzykaliów, obiektów fonograficznych i fotograficznych. Kolekcją zamkniętą jest zbiór, którego gromadzenie zostało definitywnie zakończone lub przerwane, czy to wiele wieków temu, czy zupełnie niedawno. Wspótczesne biblioteki, które kontynuują gromadzenie książek, zwykle zawierają w swych zasobach wiele zamkniętych kolekcji historycznych. Bywają to jednostki duże i małe, calości, części składowe i fragmenty, zbiory prywatne lub instytucjonalne z różnych okresów o nierównej wartości merytorycznej, artystycznej oraz historycznej. Wszystkie one są świadectwami i źródłami wiadomości o ludziach, ich działaniach i wytworach. Bywają wśród nich dzieła o najwyższej, uniwersalnej wartości, ale nawet jeśli takich brakuje, to każdy dawny zbiór książek, choćby składal się z banalnych na swoje czasy wydawnictw i nie dotyczył najwybitniejszych osobistości, jest cennym fragmentem i składnikiem ogólnego pejzażu kulturalnego, śladem potrzeb i możliwości swych twórców i użytkowników. Dlatego wspólne jest światowe dziedzictwo kulturalne zawarte w najbardziej nawet prowincjonalnych pozornie biorach $^{8}$. 
Zabytki piśmiennicze spełniają rozliczne funkcje merytoryczne, ideowe, estetyczne, emocjonalne i prestiżowe. Przede wszystkim są podstawą i nieodzownym warunkiem wielu badań naukowych. Ponadto służą celom oświatowym, popularyzatorskim, artystycznym, rozrywkowym, a czasem wręcz praktycystyczno-życiowym. Mogą np. dokumentować czyjś status, prawa majątkowe, przynależność społeczną, narodowościową, religijną, polityczną itd. Bardzo często dotarcie do właściwych obiektów jest sprawą pierwszorzędnej wagi w skali ogólnej, środowiskowej czy indywidualnej. Z drugiej strony korzystanie ze zbiorów historycznych napotyka na szczególne bariery. Wynikają one z samej specyfiki dawnych pism ich rzadkości, często wręcz unikatowości, wartości kulturalnej i materialnej, delikatności faktury, niezbędnych specjalistycznych umiejętności przy użytkowaniu. Jest kwestią bezdyskusyjną, że zbiory specjalne wymagają pieczołowitej ochrony zapewniającej im maksymalne bezpieczeństwo. Równocześnie jednak spuścizna historyczna jest dobrem, które musi funkcjonować w nauce i w świadomości społecznej. Nie może pozostawać kapitałem niedostępnym i martwym. Owa sprzeczność interesów między obowiązkiem ochrony a postulatem powszechnej dostępności stanowi trudny dylemat wspólczesnej polityki bibliotecznej. Są to problemy powszechne, niejako naturalne. W ich przezwyciężaniu coraz większą rolę odgrywa możliwość przenoszenia oryginałów na nośniki wtórne ${ }^{9}$. Niezbędne lecz trudne merytorycznie, organizacyjnie, technicznie i ogromnie kosztowne przedsięwzięcia konserwacyjne i reprograficzne wymagają ścisłej koordynacji oraz kooperacji w skali krajowej i międzynarodowej, bowiem przekraczają możliwości nawet zamożnych instytucji w krajach uważanych za bogate. W Polsce i potrzeby w tym zakresie i niemożności są tragicznie zwielokrotnione.

Oczywiście, mniej czy bardziej skomplikowany, ale dostęp do zbiorów historycznych jest możliwy tylko wtedy, gdy są one zlokalizowane i zdokumentowane. Poza tą sferą pozostają jednak ogromne zasoby dawnych książek nierozpoznane, zapomniane i zaniedbane, o istnieniu których wie tylko bardzo wąskie grono, a o zawartości - nikt, lub prawie nikt. Włączenie ich do obiegu cywilizacyjnego jest obecnie pilnym i niezwykle trudnym zadaniem.

Odnosi się to w znacznej mierze do księgozbiorów przemieszczonych i przejętych a więc tych, które w toku dziejów zmieniły właścicieli i miejsce przechowywania $^{10}$. Obecnie znajdują się $w$ innych środowiskach, niż te, przez które i dla których były tworzone. W grę mogą wchodzić przemieszczenia między różnymi państwami i narodami, albo wędrówki w ramach tych samych krajów. W jednych i drugich przypadkach bardzo często zmiany właścicieli wynikały bezpośrednio lub pośrednio z przyczyn politycznych. Ogromna jest skala tego zjawiska w Polsce, gdzie $w$ ciągu ostatnich przeszło dwóch wieków, aby już nie sięgać głębiej, przetoczyły się burze rozbiorów i obu wojen światowych - wraz z ich konsekwencjami - rujnujące mapę naszego dziedzictwa kulturalnego.

Najdotkliwsze zmiany pociągnęly za sobą grabieże i straty wojenne. Historia każdej chyba epoki i każdego zakątka ziemi zna takie przypadki. Począwszy od starożytności (osławione zabory rzymskie nie są jedynym przykładem) poprzez dzieje snuje się niechlubny wątek wywożenia księgozbiorów z ich macierzystych siedzib, czy to jako łupów wojennych, czy represji ze strony zwycięzców. Wystarczy 
przypomnieć choćby „potop” szwedzki, wojny napoleońskie, rosyjskie rekwizycje od XVIII w., czy grabieżcze akcje hitlerowców na okupowanych terenach. W wyniku takich działań wiele obiektów i zespołów zostało zniszczone. Dodajmy do tego nierzadkie przypadki celowego unicestwiania książek przez wrogów (np. spalenie przez hitlerowców po zakończeniu walk w Warszawie w 1944 r. najcenniejszych dzieł z warszawskich bibliotek). Odnotowując z żalem i potępieniem takie fakty, jako zbrodnie wojenne, jesteśmy wobec nich już zupełnie bezradni. Zaistniałe zło jest nie do naprawienia. Tkwi jednak jak cierń w świadomości poszkodowanych społeczeństw stanowiąc poważną barierę psychologiczną wobec racjonalnych obecnie, jak się zdaje, szans współpracy informacyjnej.

$\mathrm{Na}$ szczęście nie wszystkie zbiory zagrabione są bezpowrotnie stracone. Niektóre kolekcje zostały zdewastowane, rozproszone, wywiezione w mniej lub bardziej znanych kierunkach, ale gdzieś istnieją; jeśli nie w calości, to przynajmniej częściowo. Jest więc możliwość, a nawet obowiązek, dotarcia do nich, zabezpieczenia, zdokumentowania i udostępnienia zgodnie z ich przeznaczeniem.

Objęcie w posiadanie zbiorów etnicznie obcych mogło też mieć miejsce w wyniku zmian granic państwowych. Tą drogą np. po ll wojnie światowej na terenach Polski znalazły się liczne księgozbiory poniemieckie a na ziemiach naieżących do naszych wschodnich sąsiadów - polskie. Nie można w tym przypadku mówić o grabieży, lecz o stratach wojennych, wynikłych z zasady przynależności (pertytencji). Ta zasada, respektowana w konwencjach międzynarodowych, z natury swojej jest obosieczna - lub raczej wielosieczna - i trzeba ten wzgląd poważnie brać pod uwagę ilekroć chcialoby się przeciw niej występować.

Poza granicami kraju mogły znaleźć się zbiory w wyniku legalnej zależności wlaścicieli od zagranicznych ośrodków dyspozycjnych. Np. obszary jurysdykcji kościelnej nie zawsze pokrywały się z granicami państwowymi. Władze polityczne wyższego szczebla często znajdowały się poza krajami uzależnionymi. Rządzący $z$ reguły dysponowali na swoją korzyść mieniem konfiskowanym, przejmowanym od likwidowanych instytucji (np. zbiory tendencyjnie kasowanych polskich klasztorów w XIX w. wydatnie wzbogacily biblioteki państw zaborczych), lub w inny sposób kontrolowanym.

Oczywiście nie wszystkie wędrówki zbiorów za granicę dokonywały się w wyniku presji politycznej. Liczne są przykłady sprzedaży przez właścicieli fizycznych czy instytucjonalnych całych lub części kolekcji zagranicznym amatorom, choćby drogą aukcji. Regułą jest wywożenie własnego dobytku w przypadku zmiany kraju osiedlenia (choć przy takich okazjach również mogły istnieć konteksty polityczne lub ideologiczne), przekazywania na zasadzie dziedziczenia lub darowizny. Istnieją też inne, rozmaite formy dysponowania własnymi książkami na rzecz nabywców zagranicznych.

Nieco podobne są przyczyny przemieszczeń zbiorów wewnątrz kraju. Wiele kolekcji historycznych uległo translokacjom i rozproszeniom na skutek działań wojennych. Powodowały one ruinę posiadłości, zagładę, przesiedlenia lub wywłaszczenia opiekunów zbiorów. Bardzo znaczne przemieszczenia spowodowaly zmiany ustrojowe, np. w rejonie Europy środkowej i wschodniej, gdzie po $1945 \mathrm{r}$. państwa przejęly tzw. mienie opuszczone oraz zbiory podworskie $i$ dawnych 
fundacji magnackich. Przejęciu i przemieszczeniu uległy też biblioteki likwidowanych organizacji oraz instytucji. Wobec zasadniczych przemian całych struktur państwowych, samorządowych i społecznych po II wojnie światowej były to zjawiska masowe. Należy dodać, że obecnie - w latach dziewięćdziesiątych naszego wieku - w wyniku destrukcji systemu komunistycznego, znów w tym rejonie Europy zasadniczo zmienia się mapa bibliotek instytucjonalnych. Upadły lub kruszą się różne kolosy, które dysponowahy archiwami i bibliotekami o wielkiej niekiedy wartości. Jest sprawą pierwszorzędnej wagi zabezpieczenie tych kolekcji oraz ich dokumentacja. Niezależnie od wielkich przełomów politycznych w każdym żywym społeczeństwie stale zachodzą zmiany powodujące mobilność zbiorów bibliotecznych. Jedne struktury powstają, inne zanikają, łączą się, dzielą, przekształcają, przenoszą itp. Dotyczy to zarówno kolekcjonerów instytucjonalnych jak prywatnych. Zmienia się stan posiadania najbardziej nawet stabilnych bibliotek, nie mówiąc o mniejszych, choć niekiedy bardzo cennych zespołach proweniencyjnych.

Ten maksymalnie skrócony przegląd przyczyn rożproszenia księgiozbiorów historycznych, w relacjach krajowych i zagranicznych, ma na celu tylko zasygnalizowanie ogromnej skali i złożoności problemu, wymykających się powierzchownym uogólnieniom. Bardzo różne są przyczyny i okoliczności przemieszczeń i przejęć zbiorów specjalnych. Różne są też ich statusy prawne: począwszy od zupełnie legalnych, poprzez wątpliwe, aż do bezprawnych zawłaszczeń. Każdy przypadek wymaga indy widualnego rozpatrywania. Ponieważ są wśród nich delikatne kwestie własnościowe o podłożu politycznym, narodowościowym, spolecznym iwyznaniowym, wokół kolekcji przejętych narosło nadmiernie wiele niedomówień, niejasności, nieszczerości i drażliwości. Są one szczególnie dotkliwe w kontaktach międzynarodowych, skutecznie blokując nie tylko dostęp do książek, ale nawet do informacji o nich.

Pozostaje niezbitym faktem, że wiele kolekcji historycznych, które zmienity miejsca i wlaścicieli na skutek wojen i innych przyczyn politycznych (grabieże, wywłaszczenia, zmiany granic), tkwi w obcym otoczeniu, zaniedbane a czasem celowo utajniane. Co więcej owej psychozie tajemniczości podporządkowane bywają także informacje o zbiorach obcych, które znalazły się w nowych miejscach w sposób zupelnie naturalny i legalny (darowizny, spadki, zakupy) ${ }^{11}$. Nierzadko trudno oprzeć się wrażeniu, że nadgorliwość polityczna w zachowaniu tajemnicy o zbiorach przejętych jest tylko wygodnym pretekstem do ukrycia niedbałości i niekompetencji obecnych dysponentów. Ciężar właściwego utrzymania kolekcji historycznej losowo przydzielonej placówce o zupełnie odmiennym profilu częstokroć przekracza jej rzeczywiste możliwości (np. cenny obecny księgozbiór specjalistyczny w niewielkiej bibliotece publicznej). Wszak jest oczywiste, że zbiory historyczne wyizolowane ze swego właściwego środowiska, w innym miejscu obce i przypadkowe, nie znajdują tam zainteresowanych i przygotowanych czytelników. W swoim założeniu przeznaczone dla kogo innego reprezentują odmienny krąg zainteresowań, poziomów, problemów a nawet języków. Z pragmatycznego punktu widzenia współczesnej biblioteki są zbędne. Niezależnie więc od rzeczywistych wartości kulturowych traktowane bywaja jako klopotliwy balast: nie rozpoznane, nie opracowane i nie konserwowane, przechowywane w najgorszych warunkach. Taka sytuacja ma swoje życiowe uzasadnienie. Większość bibliotek, zwłaszcza w Euro- 
pie środkowej i wschodniej, boryka się z dotkliwymi trudnościami finansowymi, organizacyjnymi, lokalowymi itp. Musi dokonywać selekcji zadań nie mogąc sprostać wszystkim. W tej konkurencji ofiarami padają zbiory najmniej na co dzień wykorzystywane, czyli obce kolekcje historyczne. One również są najbardziej kosztowne i najtrudniejsze do konserwacji i opracowania. Często reprezentują obce bibliotekarzowi języki i pisma (np. cyrylickie, gotyckie, hebrajskie) a zawsze odległa problematykę, wymagającą specjalistycznego warsztatu i studiów. W efekcie cenne zbiory niszczeją zapomniane i niedostępne. Brak nawet pobieżnej ewidencji ich stanu zachowania. Być może bariery hamujące swobodny przeplyw informacji, o których tu mowa, są szczególnie silne w krajach byłego bloku socjalistycznego i między tymi krajami. Jednak ich reperkusje dotyczą calego obiegu komunikacji kulturalnej, ograniczając w istotny sposób możliwości poznawcze światowej nauki.

W rysującej się obecnie perspektywie normalizacji politycznych stosunków wewnętrznych i międzynarodowych zaistniała szansa otwarcia dróg dostępu do zbiorów przejętych i informacji o nich ${ }^{12}$. Na wlasnym terenie i w ramach swych możliwości podjęto ją Polskie Towarzystwo Bibliologiczne, stowarzyszenie naukowe o zasięgu ogólnokrajowym, powstałe w Warszawie w 1988 r., obecnie dysponujące pięciu oddziałami terenowymi (w Krakowie, Lublinie, Łodzi, Warszawie i Wroclawiu). Towarzystwo po kilkumiesięcznych dyskusjach przyjęlo w czasie obrad Forum PTB w dn. 31 maja 1990 r. "Stanowisko w sprawie swobodnego dostępu do informacji i zbiorów przemieszczonych oraz przejętych" "13 . Sprowadza się ono do kilku zasadniczych punktów:

„1. Podstawowym kryterium decyzji dotyczących losów zbiorów winno być ich dobro: bezpieczeństwo, właściwa konserwácja, opracowanie i wykorzystanie w obiegu kulturalnym.

2. Zawodowym i moralnym obowiazziem dysponentów zbiorów jest ich fizyczna ochrona oraz zapewnienie pełnego przepływu informacji oraz swobodnego zgodnego z regułami bibliotekarskimi, bez sztucznych utrudnień - dostępu do całych kolekcji i poszczególnych egzemplarzy dla ogółu zainteresowanych a zwłaszcza dla dawnych właścicieli.

3. Dla zapewnienia aktualnej, rzetelnej informacji o księgozbiorach przemieszczonych należy wypracować formy współpracy międzybibliotecznej - wewnątrzkrajowej i międzynarodowej - opartej na fachowości i lojalności. Szczególnie ważne wydaje się publikowanie informatorów centralnych i lokalnych o znaczniejszych kolekcjach, poradnictwo $w$ zakresie opracowania zbiorów etnicznie obcych, wymiana pracowników (np. stypendystów, stażystów) i informacji (np. w formie katalogów, kartotek, kwerend).

4. Przedmiotem starań Towarzystwa jest problem swobodnego dostępu do informacji i zbiorów przemieszczonych. Natomiast ewentualne dochodzenia praw własności są odrębnymi kwestiami, pozostającymi w gestii odnośnych władz.

Forum Polskiego Towarzystwa Bibliologicznego wyraża nadzieję, że przyjęcie i respektowanie wymienionych zasad przez środowiska pracowników ksiażki w Polsce i w innych zainteresowanych krajach przyczyni się do wzajemnego zrozumienia i zaufania, do usprawnienia wymiany informacji i rzeczywistego włączenia znacznej, często zagrożonej zniszczeniem bądź zapomnieniem, części dziedzictwa historycznego do żywego obiegu kultury światowej". 
Rozważając sposoby działania na rzecz swobodnego dostępu do publikacji uczestnicy Forum wysunęli propozycję zorganizowania centrum dokumentacji i informacji o zbiorach przejętych, które byłoby równocześnie bankiem danych i punktem konsultacyjnym dla zainteresowanych instytucji krajowych i zagranicznych.

Dzięki inicjatywie PTB, poparciu Ministerstwa Kultury i Sztuki oraz zrozumieniu i życzliwości Dyrekcji Biblioteki Narodowej 1 października 1990 r. powołana została w BN w Warszawie Pracownia Dokumentacji Księgozbiorów Historycznych. Na jej czele stanęła st. kustosz dypl. mgr Hanna Łaskarzewska ${ }^{14}$.

Doświadczenia z rocznego zaledwie okresu działainości Pracowni są obiecujące. Jednak to dopiero początek długiej i ciężkiej pracy, której nie wolno odkładać na później.

\section{Przypisy}

1 Ustawa z dn. 15 lutego 1962 r. o ochronie dóbr kultury i o muzeach (Dz.U. 1962 nr 10 poz. 48, R, II, art. 5, pkt 8-11); Obowiazujący do $1968 \mathrm{r}$. Dekret $z$ dn. 17 kwietnia $1946 \mathrm{r}$, o bibliotekach i opiece nad zbiorami bibliotecznymi (Dz.U. $1946 \mathrm{nr} 26$ poz. 163, Dz. I, art. 1-2); Ustawa o bibliotekach z dn. 9 kwietnia 1968 (Dz.U. $1968 \mathrm{nr} 12$ poz. 63, R. 1 art. 1).

${ }^{2}$ Por. J. Pruszyński, Ochrona zabytków w Polsce. Geneza, organizacja, prawo. Warszawa 1989 s. 15-20. W Dekrecie $(1,1)$ zawarte zostalo sformulowanie: „Biblioteki i zbiory biblioteczne zarówno krajowe, jak znajdujące się za granica a będące własnością lub $w$ posiadaniu obywateli polskich lub instytucji polskich uznaje się za narodowe mienie kulturalne powołane do służenia dobru ogólnemu". Podobnie obowiązująca dotąd Ustawa z 1968 r. (1, 1): „Biblioteki, ich zbiory i urządzenia są dobrem narodowym”; Ustawa z 1962 r. (1, 2) określa: „Dobrem kultury w rozumieniu ustawy jest każdy przedmiot ruchomy lub nieruchomy, dawny lub współczesny mający znaczenie dla dziedzictwa i rozwoju kulturalnego ze względu na jego wartość historyczną, naukową lub artystyczną".

${ }^{3}$ Ustawa z 1962 r. (1, 3.1). Cytuję w brzmieniu przyjętym w Ustawie z dn. 19 lipca 1990 r. o zmianie ustawy o ochronie dóbr kultury i o muzeach (Dz.U. $1990 \mathrm{nr} 56$ poz. 322, art. 1.2).

${ }^{4}$ Ustawa z 1962 r. (1, 3.2.).

${ }^{5}$ Podstawowe zalożenia programu przedstawiają: S. Vickers, The Fundamentals of UAP, "IFLA Journal" vol. 8, no 1, 1982, p. 42-49; M.B. Line, Universal Availability of Publications, "UNESCO Bulletin for Libraries" vol. 31, no 3, 1977, p. 141-152; „UAP Newsietter" no 1; M.B. Line, UAP and its relation to research and education. Abstract 53rd IFLA Council and General Conference. Brighton. United Kingdom, 16-21 August 1987 no 9-2.

${ }^{6}$ Por. S. Vickers, op.cit, s. 42: "The objective of UAP - Universal Availability of Publications is the widest possible availability of publications to intending users wherever and whenever they need it, as an essential element in economic, social, educational and personal development. To achieve this objective requires both positive action and the removal of barriers at all levels, from the local to the international, and at all stages, from the publication of new material to the retention of last copies."

${ }^{7}$ Por. I.R. Willison, The relevance of Universal Availability of Publications to rare and precious books, „IFLA Journal" vol. 4 no 2, 1987, p. 158-165.

${ }^{8}$ B. Bieńkowska, Kilka uwag i propozycji w sprawie badań księgozbiorów historycznych, „Studia o ksiażce" t. 16, 1986 s. 3-17.

${ }^{9}$ W skali międzynarodowej akcję mikrofilmowania cennych i rzadkich oryginalów prowadzi Komisja Ochrony i Dostępności Zbiorów (Commission on Preservation and Access) z siedzibą w Waszyngtonie, wspólpracująca w tym zakresie z Europejską Wspólnotą Gospodarczą.

10 Problemowi księgozbiorów przemieszczonych i przejętych poświęcone byly dwa posiedzenia Forum Polskiego Towarzystwa Bibliologicznego (Warszawa 20 kwietnia i 31 maja 1990). Zob. „Nowiny Polskiego Towarzystwa Bibliologicznego" $1990 \mathrm{nr} 4$ (sierpień); Doniosla inicjatywa Polskiego Towarzy. stwa Bibliologicznego, „Kwartalnik Historii Nauki i Techniki" $1990 \mathrm{nr} 4$, s. 651-653. Obszerne materiały Forum wydane zostaną w "Studiach o książce", t. 20. Materiahy te, a zwłaszcza opracowanie M. 
Cubrzyńskiej - Leonarczyk, Historyczne księgozbiory polskie i obce rozproszone na terenie Rzeczypospolitej i poza nią wykorzystane zostaly ponizej.

${ }^{11} \mathrm{Na}$ negatywne skutki ukrywania źródel pochodzenia zbiorów zwrócił ostatnio uwagę, z pozycji czytelnika, P. Spodenkiewicz, Ksiegozbiory na granicy epok, "Res publica" 1991 nr 9/10, s. 143-146.

12 Por. Dziedzictwo ważniejsze niż granice. $Z$ Wojciechem Kowalskim, pełnomocnikiem rządu ds dziedzictwa polskiego za granica rozmawia Marzena Guzowska, „Rzeczpospolita" 1991 nr 248 (23 października).

${ }^{13}$ Pelny tekst Stanowiska opublikowany zostal w ${ }_{n}$ Nowinach PTB" por. przyp. 10.

${ }^{14}$ Informacje o zadaniach i dzialalności Pracowni zob. następny artykuł niniejszego tomu.

Warszawa, październik 1991. 